\title{
An investigation of the role of background knowledge on students' performance in ESP tests
}

\author{
Ahmadvand, Mohammad \\ University of Isfahan, Iran (mohammad_ahmadvand2007@yahoo.com) \\ Barati, Hossein \\ University of Isfahan, Iran (h.barati@yahoo.com)
}

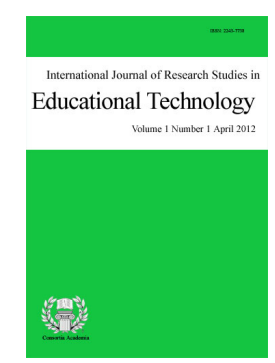

ISSN: $2243-7738$ Online ISSN: 2243-7746

\begin{abstract}
Unlike the past, recent reading theories and models define reading comprehension as an interactive process involving both reader and text characteristics (Day and Park, 2005). This interaction is influenced by different factors one of which is background knowledge. This study aimed at investigating the effect of background knowledge on the reading comprehension of two groups of homogenous students majoring in Theology and Psychology respectively. Two ESP tests were given to the two groups, one on theology and the other one on psychology, each one consisting of 40 multiple-choice items. The researchers wanted to see which of the two groups performed better in the test related to their major. The results of the study show that there was no significant difference between the two groups' performance in the two ESP tests suggesting that background knowledge is not so important in performing in ESP tests, although there were differences between the two groups regarding their knowledge and abilities on the whole. The implications of this finding will be discussed at the end.
\end{abstract}

Keywords: background knowledge; English for specific purposes; comprehension; formal schemata; content schemata 


\section{An investigation of the role of background knowledge on students' performance in ESP tests}

\section{Introduction}

Understanding written texts necessitates the use of different skills and processes such as recognition of letters, letter combinations, and word combinations, memory scan, distinguishing the main idea, understanding cause-effect relations, sequencing of ideas, retrieval of previous information stored in long-term memory, and integration of new and old information. What is crucial here, but sometimes ignored, is the role that the interaction between the reader and the text plays in negotiating meaning and what the reader brings into the act of understanding the text; meaning is not solely in the words or phrases or one that is intended by the writer but it is created by the reader through an interactive process involving the reader's background knowledge, and that sometimes the information contributed by the reader is more than that offered by the text. Comprehending written language is a kind of dynamic transaction involving the text, the socio-cultural context, and the reader (Pardo, 2004; Al Salmi, 2011; Pourhosein \& Ahmadi, 2011; Kader, 2009). Readers have different kinds of knowledge with different levels including the knowledge of language (word meanings, grammar, rhetorical structure of texts) and background knowledge, and different skills such as decoding skills, problem solving skills and higher order thinking (Pourhosein \& Ahmadi, 2011; Deshler, 2005; Cromley \& Azevedo, 2007); these cooperate to lead a reader towards an understanding of the printed message.

\subsection{Definition of Comprehension}

Reading is the most widespread skill required in different countries especially in EFL contexts and academic contexts in which the main purpose for reading is comprehension (Zhang, 2008). Comprehension has been defined as getting the correct message from a text using an interactive process which includes both top-down and bottom-up processing (Day and Park, 2005), decoding and restructuring meaning through involvement with the written material accommodating the information in the text into one's "personal agenda" (Duke, 2003), an interplay of bottom-up and top-down processing, schematic knowledge developed from one's intelligence and experiences, affect, and culture (Kader, 2009), and creating a coherent mental representation of the information presented in the text (Broek, Kendeou, Lousberg, \& Visser, 2011).

Day and Park (2005) provide a classification of types of comprehension; the list includes 1) literal comprehension which refers to understanding of facts, numbers, and time or spatial references explicitly stated in the passage in a straightforward manner, 2) reorganization which is manifested when readers can combine the information found in different parts of a passage, for example, when readers calculate the age of a person from the date of his birth mentioned at the beginning of a passage and his date of death mentioned at the end of the passage, 3) inference which takes place when a reader can retrieve information or ideas based on the presented material but not explicitly stated, 4) prediction which is based on a combination of a reader's understanding of the text and his/her knowledge of the content or the topic, relating everything in a systematic manner to foretell what will happen next, 5) evaluation which demands a "global and comprehensive judgement" about an aspect of a passage or so by the reader, and 6) personal response which is demonstrated when a reader is able to express his/her feelings toward a text or a topic, based on at least a literal understanding of the content of course. This classification tactfully illuminates different aspects and levels of a phenomenon we call comprehension, a phenomenon which, as Duke and Pearson (2002) state, involves drawing, comparing, and integrating one's prior knowledge and information with that found in the written material.

\subsection{Definition of Background Knowledge}

Different definitions of background knowledge, also known as prior knowledge or schematic knowledge, 
An investigation of the role of background knowledge on students' performance in ESP tests

have been reported in the literature: a combination of experiences with the language, the previous works read, and life experience ( Knuth \& Jones, 1991), knowledge of subject matter or conceptual knowledge and cognitive knowledge (Strangman \& Hall, 2009), context knowledge and academic experiences a person has (Marzano,2004), and all the experiences a person has had throughout his life (Bailey, 2012). Lee and Spratley (2010) believe that different sources foster background knowledge including knowledge of vocabulary, sentence structures, and rhetorical structures of different genres, and knowledge of the topic.

\subsection{Kinds of Background Knowledge}

Background knowledge has been divided by different experts into different kinds. A classification divides background knowledge into content schemata, knowledge of the world, social interaction, human intentionality, and causal relations gained because of experience, formal schemata, knowledge of organizational forms, transitional and metadiscourse markers, hierarchy of ideas, and rhetorical structures of different text types or genres gained from instruction, working at textual and discoursal levels and guiding readers' expectations, and linguistic schemata, knowledge of vocabulary, idioms, and grammar (Huang, 2009; Carrell, 1984; Armstrong, 1995).

Another comprehensive classification divides background knowledge into world knowledge, readers' experiences with the world derived from a person's social practices as a member of a community, text knowledge, readers' knowing of how texts are constructed and how ideas are organized in a text, discipline knowledge, knowledge of subject areas especially in academic contexts, and language knowledge, knowledge of vocabulary and grammatical rules especially vocabulary of specific courses (Carrell, 1988).

\subsection{How Background Knowledge Works}

Background knowledge can have both bad and good effects, taking the reader away from the text and taking him/her deeper into the text. Surely what we hope for is the right background knowledge used by a reader at the right time and for the right purpose facilitating comprehension (Armstrong, 1995; Mihalakis, 2012). Background knowledge gives directions to the mind of readers. According to Anderson and Pearson (1984), prior knowledge works in three ways: First, it helps the learners make better inferences with less effort because they can construct a mental schema which helps them understand texts by predicting. Secondly, background knowledge helps learners distinguish main ideas from supporting ideas and more important information from less important information easier. Thirdly, background knowledge activates learners' minds and helps them recall previous information faster.

The role of background knowledge in making predictions and inferences has been discussed a lot in the literature (e.g Tarchi, 2010). It seems that readers' ability to infer implicit ideas and hidden agendas constitutes a major part of comprehension (Liang \& Galden, 2009). McNamara and Kendeou (2011) classify inference types into bridging inferences and associative inferences which are closely comparable with Day and Park's (2005) definition of reorganization and prediction respectively. For inferencing, according to Stahl, Hare, Sinatra, and Gregory (1991), some domain knowledge is essential to the understanding of the relations between ideas left out by the authors and the ideas explicitly stated in the text; this takes place through a network of ideas and concepts restored from long-term memory helping learners make mental representations which in turn help create meaning.

As Kucer (2001) states, if there is agreement between the readers' prior knowledge and the information in the text, the reader assimilates the new information; otherwise, the reader accommodates the new information to make it fit his/her personal experiences and patterns. A reader makes predictions based on his/her prior knowledge and seeks to confirm his/her predictions about what will come next, so, comprehension will be greater in case there is more agreement between the reader's schemata and that of the text (Pourhosein and Ahmadi, 2011; Lipson, 1982). So, a reader plays a leading role in comprehending a written text because reading 
comprehension is not a passive activity but a dynamic and interactive process involving a triangle of the writer, the text, and the reader (Twist, Gnaldi, Schagen, \& Morrison, 2004).

Background knowledge has indirect effects on comprehension too. Tarchi (2010), for example, in a study of both direct and indirect influences of background knowledge, comes to conclude that knowledge of the topic of the text increases fluency which in turn contributes to the overall reading comprehension ability. Bekas-Cetinkaya's (2011) study also showed that unfamiliar context triggers anxiety in the readers which in turn hinders their reading comprehension ability. As McConnell (1993) states, background knowledge helps readers make inferences and predictions, confirm or reject their predictions, visualize concepts and ideas, monitor their comprehension by asking questions, distinguish important ideas in a piece of writing, and manifest their understanding. And this is what all reading is about.

\subsection{Characteristics of ESP}

ESP as a component of applied linguistics has an important feature, its 'openness to insights from other disciplines', with its main concern being analysis of needs and texts of special disciplines to help learners communicate more effectively during the specific tasks required in the study or workplace (Amirian, 2013). ESP texts as well as tests made based on them develop from needs analysis and hence are related to specific courses of study, occupations, or activities covering correlated content, themes and topics. They involve specific vocabulary, or general vocabulary with specific meanings, and their technical language contains a high frequency of special grammatical structures (e.g. passive sentences). These allow for special discoursal and semantic characteristics to fulfill communicative functions enabling the people in a particular academic, professional or vocational field to convey their specific meaning more effectively. These features allow us to have different language varieties like business English, travel English, etc., to help the learners have better performance at their target language use situation, so they are goal-oriented in nature (Tratnik, 2008; Strevens, 1988; Robinson, 1991).

ESP is seen to be characterized by rich input, content derived from needs analysis, a practical language for learners, and tasks which are meaningful for the very context the learners are involved in (Lo, 2012). Also an important characteristic of ESP is that in ESP English is a means rather than an end in itself making it different from EGP (Hosseini Maasum, 2011) and usually targeted at adults who have already learned some English and are somehow familiar with different educational technologies to be able to perform their professional functions (Pranckeviciute and Zajankaukasite, 2012). All these show the necessity of research in the area of ESP to understand its different dimensions and functions in the academic context.

\section{A review of related research}

Most research done in the area has focused on the effect of topical or cultural knowledge on reading ability. Tarchi (2010), for instance, investigated the relationship between knowledge of history and the reading comprehension of history texts finding close ties between the two. Al-Hassan (2012) provided pre-reading instruction on "lottery" for his experimental group, finding "strong positive effects of background knowledge treatment". Stahl et al. (1991) found that both domain knowledge and knowledge of vocabulary help improve comprehension and recall of different aspects of a passage content. Droop and Verhoeven (1998) concluded that cultural familiarity has a "facilitating effect on both reading comprehension and reading efficiency". Stevens (1980) found that the experience a reader brings to the understanding of a selection affects the depth of his/her understanding.

Salmani-Nodoushan (2003) found that text familiarity had a positive effect on learners' test and task performance and that it interacted significantly with task type, and language proficiency. Aghajani, Motahari, and Qahraman (2013), investigated the effect of text familiarity, in their case the electronic module, on university students and found that electronics majors outperformed English majors in the ESP reading test. 
There are studies which show limitations and different interpretations of background knowledge too. Chou (2011), for example, in a study done in Taiwan concluded that knowledge of vocabulary can compensate for a lack of background knowledge. Stahl and Jacobson (1986) showed that pre-teaching of content knowledge or topic can improve readers' comprehension but it cannot compensate for the problems caused by text difficulty. Garth-McCullough (2008) studied the effect of culturally-bound prior knowledge on students of low, mid, and high levels and found that it was especially effective for mid-level students. Awabdy (2012) showed that the effect of background knowledge, in this case conceptualized as topic familiarity, varied from passage to passage and because of the difficulty level of the passages.

Regarding the role of background knowledge, two somehow ignored areas need to be explored more of course. Although there are a large number of studies on the relationship between background knowledge and L1 reading and that the findings of these studies have been "suspected" to be true in L2 reading too, L2 reading needs more investigation (Pourhosein \& Ahmadi, 2011). And according to Lee and Spratley (2010) content areas bring more obstacles to the act of reading comprehension and that building prior knowledge of academic disciplines is a must. So, it is essential to cultivate the role of background knowledge in ESP learning.

\subsection{This Study}

Research Question - This study aims at answering the following question: Does background knowledge affect comprehension of ESP texts?

Research Hypothesis - Based on the review of the literature and the research question, we made the following hypothesis: Students who have a good command of background knowledge of their major will comprehend ESP texts of their major better.

\section{Method}

\subsection{Participants}

The participants of this study consisted of two homogenous groups each consisting of 20 sophomore male and female students in Payam-e-Noor University of Malāyer, Iran. These two groups were selected from 75 students (38 theology students and 37 psychology students) who took a TOEFL test on grammar, reading, and vocabulary. One group majored in theology and the other group majored in psychology. Neither had passed their ESP courses yet.

\subsection{Materials}

The ESP tests of theology and psychology which were given to the participants were chosen from Payam-e-Noor University ESP tests administered and released by this university. These tests are made by experts in ESP and administered throughout the country in all branches of this university which used the same ESP text-books. Each test consisted of 40 multiple-choice questions including sentence comprehension questions and specific vocabulary questions. The use of vocabulary questions by the researchers is closely compatible with McNamara and Kendeou (2011), Chou (2011), and Awabdy's (2012) beliefs that vocabulary knowledge, especially ESP vocabulary, and background knowledge are closely interrelated because both of them contribute to the establishment of conceptual knowledge of readers, and Lee and Spratley's (2010) idea that words constitute a major source of prior knowledge, or Pulido's (2007) study that showed a close relationship between topic familiarity and lexical inferencing and retention.

\subsection{Procedures}

Seventy-five university students (38 theology students and 37 psychology students) were asked to take a 
Ahmadvand, M. \& Barati, H.

TOEFL test on grammar, reading, and vocabulary. From these students two homogenous groups consisting of 20 male and female students each were selected. Two ESP tests were given to the two groups, an ESP test on theology and an ESP test on psychology. The scores of the groups for each test were analyzed statistically using matched T-test to see which group had performed better in these tests.

\section{Data Analysis and Results}

As two tests had been given to each group, matched T-test was applied to the results of each group. The results of the matched T-tests are reported in tables 1 and 2 respectively.

\section{Table 1}

Paired Samples T-tests of Psychology Students

\begin{tabular}{llllcll}
\hline The Tests & $\mathrm{N}$ & Mean & $\mathrm{SD}$ & $\mathrm{t}$ & $\mathrm{df}$ & $\mathrm{Sig}$ \\
\hline ESP Psychology & 20 & 14.5500 & 5.69834 & -.672 & 19 & .510 \\
ESP Theology & 20 & 15.6500 & 6.40127 & & & \\
\hline
\end{tabular}

Here, level of significance is .510 (higher than .05); therefore, the performance of psychology students in the two tests is not significant. In other words, among psychology students, background knowledge did not significantly affect performance in English. The means suggest that in this group, the students performed better in the test of ESP Theology but as it was mentioned this difference was not significant.

Table 2

Paired Samples T-tests of Theology Students

\begin{tabular}{lllcccc}
\hline The Tests & $\mathrm{N}$ & Mean & $\mathrm{SD}$ & $\mathrm{t}$ & $\mathrm{df}$ & $\mathrm{Sig}$ \\
\hline ESP Psychology & 20 & 11.9500 & 7.50070 & -2.46 & 19 & .808 \\
ESP Theology & 20 & 12.2500 & 5.58075 & & & \\
\hline
\end{tabular}

Here, level of significance is .808 (higher than .05); therefore, the performance of theology students in the two tests is not significant either. In other words, among theology students, background knowledge did not significantly affect performance in English. The means suggest that theology students performed better in their own ESP test but as it was mentioned this difference was not significant.

\section{Discussions}

The results of the study show interesting points. First, unlike many studies done before on background knowledge, this study shows that background knowledge is not a significant factor. The difference of this study and the previous ones reviewed in the literature is that most of them had focused on a "very" specific piece of topical or cultural knowledge (e.g. lottery) or for example history in general and not as a specific field of expertise or course of study while this study included a whole range of ideas and concepts in psychology and theology and that the students were expected to know "everything" related to their major.

The second noticeable point is that while we had 40 test items in each test, the mean of both groups in all tests is below 20; the passing grade in Iran, which is plausible because these students had not passed any ESP courses yet, so they were not familiar with many specific concepts and words in English.

Another point worth consideration is a better performance of psychology students not only in ESP Psychology but also in ESP Theology. A quick analysis of the Theology tests showed that there were some questions in the test which had a combined tone of both psychology and theology. Also, the difficulty level of the theology test may be lower than that of the psychology test because some test items, though their context sentence was concerning theology, asked for general words; this is also the same for theology students who performed better in theology tests, maybe not because of background knowledge but because of lower difficulty level of theology tests. This finding is compatible with Garth-McCullough (2008) and Awabdy's (2012) studies 
An investigation of the role of background knowledge on students' performance in ESP tests

which showed that text difficulty influence the effectiveness of background knowledge.

\subsection{Implications of the Study}

The implications of the results of this study may be interesting. We can ask ourselves some questions: Can general knowledge of English compensate for ESP knowledge? Shall we exclude any attempt to teach ESP at all? Shall we leave the learning of ESP, which many teachers believe is just a combination of specific vocabulary; which is more important than general academic vocabulary only a bit (Sage, 2013), and an "emphasis" on some general structures, to the students themselves? Is ESP really needed and useful in developing students' English knowledge? Or maybe we should focus more on developing students' General English? This question is consistent with Salmani-Nodoushan's (2003) study in which he found that language proficiency had the greatest influence on his subjects' overall test and task performance in comparison to text familiarity and task type. We compared two groups of students of humanities; we believe that comparing two completely different groups of students, for example medicine and theology, may yield more interesting results.

Other implications derived are as follows: If ESP is important in improving the academic skills required for university students, does it receive the necessary attention in the upcoming exams like MA and PhD exams or the exams that volunteers take when entering the job market? If it is not that much necessary, why is it included in most graduate programs? These are important questions which must be answered by further research. Another important potential area which is needed to be investigated is the use of new technology (e.g. cell phones, the Internet, etc,) in teaching and learning ESP. Also independent learning by the students themselves versus classroom learning is an important issue to be investigated. Of course, this is to be done after we have come up with a decision on the importance of EGP and ESP, and the similarities and differences between the two.

\section{Conclusion}

The main goal of teaching, after all, is helping our students learn and improve their required academic skills (Rouf, 2012). The use of ESP courses in developing students' English proficiency for enabling them to perform their tasks in English (e.g. writing an essay, giving a lecture, or attending a conference held in English which are required abilities for students especially M.A. or Ph.D. students) is an important issue to be considered and studied. This study showed that general English may be all that students need to be able to perform well in contexts requiring performance in English, although more research is needed to establish this finding. As Popescu (2010) states, it is really difficult to tell where EGP ends and ESP starts.

\section{References:}

Aghajani, M., Motahari, M., \& Qahraman, V. (2013). The effect of text familiarity and reading tasks on ESP test performance. Journal of Emerging Trends in Computing and Information Sciences, 4(3), 296-302.

Al-Hassan, A. (2012). Effects of schemata on Petra University students' reading discourse. Retrieved November 12,2012 , from

http://www.uop.edu.jo/download/Research/members/67_983_The_effects_of_culture_and_schemata_o n_reading_discourse_of_university_students.pdf

Al Salmi, M. (2011). Schemata (background knowledge) and reading comprehension for EFL students. Majalat Bohoosoltarbiyate Noiya, 22, 695-708.

Amirian, S. M. R. (2013). Teaching reading strategies to ESP readers. International Journal of Research Studies in Educational Technology, 2(2), 19-26. http://dx.doi.org/10.5861/ijrset.2013.318

Anderson, R. C., \& Pearson, P. D. (1984). In S. A. Stahl, V. C. Hare, R. Sinatra, \& J. F. Gregory (1991), Defining the role of prior knowledge and vocabulary in reading comprehension: The retiring of number 41. Journal of Reading Behavior, 23(4), 487-508.

Armstrong, J. O. (1995). Prior knowledge, text features, and idea maps. USA: University of Illinois. 
Awabdy, G. W. (2012). Background knowledge and its effect on standardized reading comprehension test performance. Unpublished doctoral dissertation, University of California.

Bailey, E. (2012). Prior knowledge improves reading comprehension: Strategies to help students with dyslexia improve reading comprehension. Retrieved November 14, 2012, from http://specialed.about.com/od/readingliteracy/a/prior-knowledge-comprehension.htm

Bekas-Cetinkaya, Y. (2011). Foreign language reading anxiety: A Turkish case. The Journal of Language Teaching and Learning, 1(2), 44-56.

Broek, P. V., Kendeou, P., Lousberg, S., \& Visser, G. (2011). Preparing for reading comprehension: Fostering text comprehension skills in preschool and early elementary school children. International Electronic Journal of Elementary Education, 4(1), 259-268.

Carrell, P. L. (1984). The effects of rhetorical organization on ESL readers. TESOL Quarterly, 18(3), 441-469. http://dx.doi.org/10.2307/3586714

Carrell, P. L. (1988). In A. Pourhosein Gilakjani, \& M. Ahmadi (2011). The Relationship between L2 reading comprehension and schema theory: A matter of text familiarity. International Journal of Information and Education Technology, 1(2), 142-149.

Chou, P. T. (2011). The effects of vocabulary knowledge and background knowledge on reading comprehension of Taiwanese EFL students. Electronic Journal of Foreign Language Teaching, 8(1), 108-115.

Cromley, J. G., \& Azevedo, R. (2007). Testing and refining the direct and inferential mediation model of reading comprehension. Journal of Educational Psychology, 99(2), 311-325. http://dx.doi.org/10.1037/0022-0663.99.2.311

Day, R. R., \& Park, J. (2005). Developing reading comprehension questions. Reading in a Foreign Language, 17(1), 60-73.

Deshler, D. (2005). In A. D. Warsnak (2006). The effects of activating prior knowledge before reading on students with and without learning disabilities (p. 1). Unpublished bachelor thesis, Wichita State University.

Droop, M., \& Verhoeven, L. (1998). Background knowledge, linguistic complexity, and second-language reading comprehension. Journal of Literacy Research, 30(2), 253-271. http://dx.doi.org/10.1080/10862969809547998

Duke, N. (2003). In L. S. Pardo (2004). What every teacher needs to know about comprehension. The Reading Teacher, 58(3), 272-280.

Duke, N. K., \& Pearson, P. D. (2002). Effective practices for developing reading comprehension. In A. E. Farstrup \& S. J. Samuels (Eds.), What research has to say about reading (3rd ed.). (pp. 205-242). Newark: International Reading Association, Inc.

Garth-McCullough, R. (2008). Untapped cultural support: The influence of culturally bound prior knowledge on comprehension performance. Reading Horizons, 49(1), 1-30.

Hosseini Maasum, S. M. (2011). The role of general background in the success of ESP courses: Case study in Iranian universities. Literacy Information and Computer Education Journal, 2(3), 424-433.

Huang, Q. (2009). Background knowledge and reading teaching. Asian Social Science, 5(5), 138-142.

Kader, C. C. C. (2009). Teaching reading in the foreign language classroom. VIDYA, 28(1), 105-112.

Knuth, R. A., \& Jones, B. F. (1991). What does research say about reading? Retrieved November 16, 2012, from http://www.academicpsychiatry.org/htdocs/Fidlerdocs/Education/Faculty_Development/educational-the ory/reading-research.htm

Kucer, S. B. (2001). In L. S. Pardo (2004). What every teacher needs to know about comprehension. The Reading Teacher, 58(3), 272-280.

Lee, C. D., \& Spratley, A. (2010). Reading in the disciplines: The challenges of adolescent literacy. New York: Carnegie Corporation of New York.

Liang, L. M., \& Galda, L. (2009). Responding and comprehending: Reading with delight and understanding. The Reading Teacher, 63(4), 330-333. http://dx.doi.org/10.1598/RT.63.4.9

Lipson, M. Y. (1982). Learning new information from text: The role of prior knowledge and reading ability. 
An investigation of the role of background knowledge on students' performance in ESP tests

Journal of Reading Behaviour, 14(3), 243-261.

Lo, Y. G. (2012). ESP versus EGP: A case study of an ESP program for vocational high school students of tourism. Taiwan International ESP Journal, 3(2), 71-100.

Marzano, R. J. (2004). Building background knowledge. Alexandria: Association for Supervision and Curriculum Development.

McConnell, S. (1993). Talking drawings: A strategy for assisting learners. Journal of Reading, 36(4), 260-269.

McNamara, D. S., \& Kendeou, P. (2011). Translating advances in reading comprehension research to educational practice. International Electronic Journal of Elementary Education, 4(1), 33-46.

Mihalakis, V. (2012). Background knowledge and close reading. Retrieved November 12, 2012, from http://ifl.lrdc.pitt.edu/ifl/index.php/blog/index/background_knowledge_and_close_reading

Pardo, L. S. (2004). What every teacher needs to know about comprehension. The Reading Teacher, 58(3), 272-280. http://dx.doi.org/10.1598/RT.58.3.5

Popescu, A. (2010). A general view on the relationship between ESP and EGP. Professional Communication and Translation Studies, 3(1-2), 49-52.

Pourhosein Gilakjani, A., \& Ahmadi, M. (2011). The relationship between L2 reading comprehension and schema theory: A matter of text familiarity. International Journal of Information and Education Technology, 1(2), 142-149. http://dx.doi.org/10.7763/IJIET.2011.V1.24

Pranckeviciute, V., \& Zajankauskaite, Z. (2012). Adjusting an ESP course to students' needs in tertiary education: A case study. Studies About Languages, 21, 115-123.

Pulido, D. (2007). The effects of topic familiarity and passage sight vocabulary on L2 lexical inferencing and retention through reading. Applied Linguistics, 28(1), 66-86. http://dx.doi.org/10.1093/applin/aml049

Robinson, P. (1991). ESP today: A practitioner's guide. Hemel Hempstead: Prentice Hall International.

Rouf, K. A. (2012). Moving towards democratic classrooms for the students at the University of Toronto. International Journal of Research Studies in Educational Technology, 1(2), 3-15. http://dx.doi.org/10.5861/ijrset.2012.114

Sage, C. (2013). Is there an "applied linguistics" vocabulary? Questioning disciplinary delineation in EAP wordlist construction. The Asian ESP Journal, 9(1), 123-146.

Salmani-Nodoushan, M. A. (2003). Text familiarity, reading tasks, and ESP test performance: A study on Iranian LEP and NON_LEP university students. The Reading Matrix, 3(1), 1-14.

Stahl, S. A., \& Jacobson, M. G. (1986). Vocabulary difficulty, prior knowledge, and text comprehension. Journal of Reading Behaviour, 18(4), 309-323.

Stahl, S. A., Hare, V. C., Sinatra, R., \& Gregory, J. F. (1991). Defining the role of prior knowledge and vocabulary in reading comprehension: The retiring of number 41. Journal of Reading Behaviour, 23(4), 487-508.

Stevens, K. C. (1980). The effect of background knowledge on the reading comprehension of ninth graders. Journal of Reading Behavior, 12(2), 151-154.

Strangman, N., \& Hall, T. (2009). Background knowledge. Retrieved November 15, 2012, from http://aim.cast.org/learn/historyarchive/backgroundpapers/background_knowledge

Strevens, P. (1988). ESP after twenty years: a re-appraisal. In M. Tickoo (Ed.), ESP: State of the art (pp. 1-13). Singapore: SEMAEO Regional Centre.

Tarchi, C. (2010). Reading comprehension of informative texts in secondary school: A focus on direct and indirect effects of reader's prior knowledge. Learning and Individual Differences, 20(5), 415-420. http://dx.doi.org/10.1016/j.lindif.2010.04.002

Tratnik, A. (2008). Key issues in testing English for specific purposes. Scripta Manent, 4(1), 3-133.

Twist, L., Gnaldi, M., Schagen, I., \& Morrison, J. (2004). Good readers but at a cost? Attitudes to reading in England. Journal of Research in Reading, 27(4), 387-400.

http://dx.doi.org/10.1111/j.1467-9817.2004.00241.x

Zhang, X. (2008). The effects of formal schemata on reading comprehension - An experiment with Chinese EFL readers. Computational Linguistics and Chinese Language Processing, 13(2), 197-214. 
Ahmadvand, M. \& Barati, H.

\section{Appendixes}

\section{Appendix 1}

The Scores of ESP Tests of Psychology Students

\begin{tabular}{|c|c|c|c|}
\hline \multirow{21}{*}{$\begin{array}{l}\text { Group One } \\
\text { Psychology Students }\end{array}$} & Students & Scores of ESP Psychology Test & Scores of ESP Theology Test \\
\hline & 1 & 12 & 16 \\
\hline & 2 & 15 & 19 \\
\hline & 3 & 12 & 10 \\
\hline & 4 & 15 & 4 \\
\hline & 5 & 9 & 19 \\
\hline & 6 & 27 & 16 \\
\hline & 7 & 12 & 10 \\
\hline & 8 & 9 & 10 \\
\hline & 9 & 9 & 19 \\
\hline & 10 & 21 & 21 \\
\hline & 11 & 21 & 28 \\
\hline & 12 & 24 & 10 \\
\hline & 13 & 12 & 13 \\
\hline & 14 & 12 & 22 \\
\hline & 15 & 9 & 7 \\
\hline & 16 & 24 & 22 \\
\hline & 17 & 12 & 10 \\
\hline & 18 & 9 & 13 \\
\hline & 19 & 12 & 25 \\
\hline & 20 & 15 & 19 \\
\hline
\end{tabular}

Appendix 2

The Scores of ESP Tests of Theology Students

\begin{tabular}{|c|c|c|c|}
\hline \multirow{21}{*}{$\begin{array}{l}\text { Group Two } \\
\text { Theology Students }\end{array}$} & Students & Scores of ESP Psychology Test & Scores of ESP Theology Test \\
\hline & 1 & 18 & 25 \\
\hline & 2 & 17 & 13 \\
\hline & 3 & 3 & 4 \\
\hline & 4 & 15 & 7 \\
\hline & 5 & 27 & 22 \\
\hline & 6 & 12 & 16 \\
\hline & 7 & 6 & 13 \\
\hline & 8 & 24 & 16 \\
\hline & 9 & 0 & 7 \\
\hline & 10 & 15 & 19 \\
\hline & 11 & 15 & 15 \\
\hline & 12 & 15 & 10 \\
\hline & 13 & 0 & 10 \\
\hline & 14 & 15 & 10 \\
\hline & 15 & 15 & 10 \\
\hline & 16 & 9 & 13 \\
\hline & 17 & 0 & 4 \\
\hline & 18 & 9 & 7 \\
\hline & 19 & 15 & 16 \\
\hline & 20 & 9 & 10 \\
\hline
\end{tabular}


Appendix 3

The ESP Psychology Questions

Part A: Choose the item which has the same meaning as the underlined parts.

1. Heredity and environment both influence intelligence.
a. strand
b. segment
c. synthesis
d. genetic make-up

2. Women are better at identifying emotions from facial expressions than men.
a. feelings
b. tensions
c. shows
d. combinations

3. You can convert your discipline from sociology to psychology.
a. adjust
b. transform
c. adapt
d. elicit

4. Prolonged exposure to the sun affects your skin.
a. being uncovering
b. hazard
c. caregiver
d. conception

5. Please don't ask me to play the guitar, I'm out of practice.
a. impulse
b. root
c. exercise
d. conflict

6. You should eliminate wrong words from an essay.
a. offset
b. remove
c. conduct
d. sweat

7. Some patients show nervous tension, depression, and insomnia.
a. pressure
b. homeostasis
c. goal
d. motivation

8. Which of the following is not considered an emotion?
a. joy
b. anger
c. fear
d. thinking

9. He learned to distinguish a great variety of birds, animals, and plants.
a. discriminate
b. assume
c. urge
d. hide

10. Genetic factors play a major role in the development of anxiety disorders.
a. abnormal
b. important
c. vague
d. psychiatric

11. Many depressed people consider suicide as a way to escape from the unhappiness of their lives.
a. borderline personality disorder
b. self-image
c. dependent personality disorder
d. self- murder

12. Irrational beliefs help to produce clinical anxiety and depression.
a. Awful
b. Inadequate
c. Reasonless
d. Careful

Part B: Choose the best item to fill the blanks.

13. In humanistic psychology, Maslow considered to be the highest of human motives.
a. self-actualization
b. structuralism
c. functionalism
d. psychotherapy

14. What perspective in psychology assumes that unconscious is the most powerful force behind most behaviour?
a. cognitive psychology
b. humanism
c. behaviourism
d. psychoanalysis

15. Scientists use mathematical techniques to .............the results and determine whether they are significant or not.
a. interpret
b. compensate
c. remove
d. reduce

16. You can think of the as the "effect".
a. self-report
b. correlational design
c. dependent variable
d. descriptive design

17. The word "trait" is closest in meaning to
a. gene
b. characteristic
c. chromosome
d. behaviour

18. Everybody at school experiences exam.
a. seldom
b. trait
c. outward
d. anxiety

19. The word "reflex" is closest in meaning to
a. midbrain
b. emotions
c. aggression
d. reaction

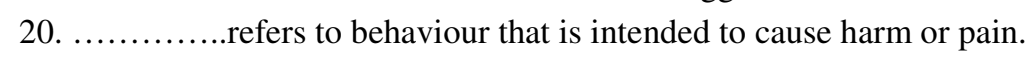



a. Emotion are chemical senses.
a. cortex
b. coordination
c. taste
d. air

22. Newborn human brain is responsive to the environment, allowing to shape human nature.
a. pregnancy
b. rubella
c. butterfly
d. nurture

23. One of the most widespread natural ...is flooding.
a. hazards
b. natures
c. sensations
d. nurtures

24. Adolescents with can form hypotheses and systematically test them.
a. concrete concepts
b. abstract concepts
c. eternality
d. egocentrism

25. Difficulty in viewing the world from someone else's perspective is...
a. animistic thinking
b. puberty
c. tummy
d. egocentrism

26. Maturing of the sexual functions means that he/she is reaching the age of
a. crawl
b. task
c. puberty
d. eternality

27. New generations of adolescents are .......to parents' criticism.
a. sensitive
b. normal
c. novel
d. geometric

28. Algorithms and heuristics are two important strategies for
a. mindset
b. problem solving
c. production
d. challenge

29. Children can be as poor readers as early as age four.
a. identified
b. transformed
c. suffered
d. multiply

30. The doctor has prescribed some drugs to the pain.
a. compel
b. propose
c. involve
d. alleviate

31. The interview shows that the patient has auditory
a. source
b. relatedness
c. deprivation
d. autonomy

32. A situation may evoke pleasure or ...... depending on how we appraisal it.
a. distress
b. survival
c. home-sickness
d. sex-differences

33. Several present-day life situations may produce a great deal of..........
a. aim
b. stress
c. diabetes
d. self-control

34. Freud said that most of our speech, thoughts, feelings or actions are motivated by
a. the conscious
b. the unconscious
c. dreams
d. the preconscious

35. Rogers developed the concept of ........ to help people achieve self-fulfillment.
a. slip of the tongue
b. the conscious
c. unconditional positive regard
d. the unconscious

36. An observable manifestation of a physical or mental disorder is ......
a. criterion
b. version
c. statistic
d. symptom

37. People are confused about the difference between psychology and .......
a. anxiety
b. psychiatry
c. bipolar disorder
d. mood disorder

38. Depression is one of the strongest predictors of ........ .
a. evaluation
b. indifference
c. suicide
d. cluster

39. He wants to how the human brain will work.
a. reject
b. explore
c. inspire
d. abuse

40. In ........, therapists apply the principles of learning techniques to treat psychological disorders.
a. cognitive therapy
b. behavior therapy
c. humanistic therapy
d. psychoanalytic therapy 


\section{Appendix 4}

\section{The ESP Theology Questions}

\section{Part A: Choose the item which has the same meaning as the underlined parts.}

1. In passing, it should be noted that all disciplines of thought and life have their mythology of guiding images and unproven assumptions.
a. seeds
b. creeds
c. claims
d. suppositions

2. The second distinguishing characteristic is that religious salvations tend to aim at total, absolute, and sometimes transcendent fulfillment of human needs.
a. undesirable
b. obnoxious
c. elevated
d. anxious

3. Analogies may be drawn to magic formulas and scientific experiments, and the resemblance is indeed meaningful.
a. demotion
b. discrepancy
c. likeness
d. difference

4. This, of course, is not to forget the multitudinous godlings, bodhisattvas, and spirits who are given ritual reverence in popular adaptations of the high religion to human need.
a. evocative
b. respective
c. limited
d. numerous

5. He does not flee but remains to worship and become the bearer of a prophetic message to his people.
a. reject
b. abandon
c. embrace
d. stick

6. It should be observed in passing that the religious person would not be satisfied with such analyses.
a. dismayed
b. aware
c. acquisitive
d. pleased

7. The most recent and influential formulation of sacredness as the unique and irreducible essence of all religious experience has been that of Mircea Eliade.
a. undividable
b. unattainable
c. inattentive
d. intentional

8. Although man shares many elements with other species of animals and plants, the one special characteristic which distinguishes man is intellect.
a. types
b. sequences
c. functions
d. samples

9. The evil actions cause the wretchedness of man.
a. research
b. unhappiness
c. sympathy
d. beauty

10. The consciousness of revelation is a mysterious and unknown form of consciousness.
a. clear
b. secret
c. definite
d. absolute

11. The life of human is not eternal. Which one is not related to the underlined word?
a. limited
b. endless
c. timeless
d. without end

12. God and his angels are immaterial.
a. concrete
b. abstract
c. touchable
d. visible

13. Quran, depending on the unique sovereignty of God, commands people to accept the principles of faith.
a. affirmation
b. authority
c. judgment
d. compassion

14. Quran prohibits people from committing certain actions.
a. prevents
b. lets
c. makes aware
d. informs

15. The Divine Compassion includes everybody and everything in this world. Which one differs from the underlined word?
a. blessing
b. mercy
c. pity
d. power

16. The iniquitous deeds lead to misery in this world and the next.
a. good
b. evil
c. proper
d. useful

\section{Part B: Choose the best item to fill the blanks.}

17. Not surprisingly, his efforts ....... with opposition from the theological community.
a. exposed
b. met
c. read
d. fed 
18. The claim of the sophist and the which negates reality can never be true.
a. intelligent
b. omnipotent
c. skeptic
d. ontological

19. The Holy Quran ...... the multitude of men in the knowledge of God through different ways.
a. instructs
b. destructs
c. consists
d. discovers

20. Every reality has a beyond which it cannot extend its existence.
a. sky
b. boundary
c. heaven
d. journey

21. The Divine Essence transcends all........
a. limitations
b. ablutions
c. recitations
d. associations

22. Each ...... depends for its coming into being upon causes and conditions.
a. reference
b. messenger
c. phenomenon
d. seal

23. In many Buddhist and Hindu contexts the religious community is little more than those in the who attend various religious ceremonies in the local temple and often come on purely personal quests.
a. regrettable work
b. interesting act
c. surrounding area
d. remarkable saying

24. Man is free in his actions but not
a. allegiant
b. argumentative
c. testimonial
d. independent

25. Man sees his happiness and ..... in gaining complete freedom.
a. perfection
b. doubt
c. multitude
d. certainty

26. Revealed religion in general ..... of two parts: doctrine and practice or method.
a. tolerates
b. disbelieves
c. punishes
d. consists

27. In order to confirm and ascertain the call of prophecy there is need of .... and demonstration.
a. sword
b. proof
c. niece
d. tent

28. The Prophet was ........ with painful reaction in his invitation.
a. rewarded
b. established
c. faced
d. created

29. Islam is a religion whose ........ are based on the truth and the real welfare of mankind.
a. generations
b. procreations
c. individuals
d. injunctions

30. A superficial view would regard death as the ..... of man.
a. perfection
b. marriage
c. worship
d. annihilation

31. Faith in the Day of ...... is on the same scale in its importance as faith in God.
a. meditation
b. creation
c. ignorance
d. society

32. Creation is not limited to this world.
a. withered
b. bleeding
c. visible
d. theological

33. The Prophet foretold seditions and ....... which would entangle Islamic society after his death.
a. tribulations
b. hospitalities
c. revelations
d. appreciations

34. There is a real ....... between good and evil actions and the kind of life that is prepared for eternity.
a. relationship
b. reality
c. realization
d. internalization

35. Everything in itself is no more than a (n)...... and a dream.
a. sublime
b. avenger
c. encouragement
d. tale

36. The doctrine that there is no external or objective truth is.......
a. objectivism
b. subjectivism
c. realism
d. determinism

37. A person who believes in more than one god is
a. monotheist
b. polytheist
c. believer
d. theologist

38. During then lifetime of the Prophet of God...... Marriage was practiced.
a. temporary
b. subsidiary
c. submissive
d. ethical

39. A prophet has the power of initiating men into Divine Mysteries.
a. relative
b. heedless
c. invited
d. esoteric

40. There are those for whom there is no reality beyond ........ existence.
a. physical
b. moody
c. eloquent
d. habitual 